\title{
Preparasi Polimer Hibrid dengan Metode Sol-Gel dan Penerapannya untuk Komponen Mikro-Optik
}

\author{
Pina Pitriana ${ }^{1 *}$, dan Rahmat Hidayat ${ }^{2}$ \\ 1,2 Laboratorium Fisika Magnetik dan Fotonik, Kelompok Keilmuan Fisika \\ Magnetik dan Fotonik, Fakultas Matematika dan Ilmu Pengetahuan Alam, Institut \\ Teknologi Bandung, \\ Jl. Ganesha no. 10 Bandung, Indonesia, 40132 \\ ${ }^{1}$ Program Studi Pendidikan Fisika, Fakultas Tarbiyah dan Keguruan, Universitas \\ Islam Negeri Sunan Gunung Djati Bandung, \\ Jl. AH Nasution No. 105, Indonesia, 40614 \\ *pina.pitriana@gmail.com \\ Telp/hp: 089664723738
}

\begin{abstract}
ABSTRAK
Polimer hibrid merupakan gabungan antara polimer organik dan anorganik. Penggabungan tersebut diharapkan akan menghasilkan sifat unggul dari bahan organik dan anorganik yang dapat dimanfaatkan untuk aplikasi. Polimer hibrid dapat digunakan untuk membuat pola dalam aplikasi mikro optik seperti pandu gelombang. Dalam penelitian ini dibuat variasi film tipis polimer hibrid dengan variasi konsentrasi berat fotoinisiator dan termoinisiator, selain itu dibuat pola pandu gelombang dengan proses fotopolimerisasi. Pembuatan polimer hibrid dilakukan dengan metode sol-gel dan fotopolimerisasi. Proses sol-gel menghasilkan rantai polimer anorganik, sedangkan proses fotopolimerisasi menghasilkan rantai polimer organik. Setelah proses fotopolimerisasi, rantai organik dan anorganik akan berikatan silang (cross-linking). Spektrum reflektansi dari film tipis polimer hibrid sebelum, sesudah fotopolimerisasi dan setelah postbake terdapat perbedaan fasa gelombang yang menunjukkan perbedaan ketebalan
\end{abstract}


film. Sampel dengan variasi konsentrasi berat Irgacure 819 sebesar 0,3\%wt dan $2 \%$ wt mengalami penyusutan volume film masing-masing 2,44\% dan 4,93\%. Sampel dengan penambahan variasi konsentrasi berat Dicumyl peroxide sebesar $1 \%$ wt dan $10 \%$ wt mengalami penyusutan volume film masing-masing $8,34 \%$ dan $5,83 \%$. Pola pandu gelombang dihasilkan dengan proses fotopolimerisasi yang diikuti dengan proses etching, menghasilkan pandu gelombang dengan bentuk struktur kanal persegi yang baik dan tidak terputus-putus. Hal tersebut mengindikasikan proses polimerisasi rantai organik telah berjalan dengan baik dan dapat bertahan setelah dilakukan etching.

Kata Kunci : polimer hibrid; proses sol-gel; fotopolimerisasi; pola pandu gelombang; etching

\section{ABSTRACT}

Hybrid polymer is composite between organic and inorganic polymer. This composite could make good properties from organic and inorganic which can be used for applications. Hybrid polymer can be used as photo-patternable material to produce micro-optical components like waveguide. In this work, weight concentration of photoinitiator and thermoinitiator in hybrid polymer thin film was varied. Else, waveguide pattern was fabricated using photolithographic etching process. Sol-gel method and photo-polymerization were used to synthesis hybrid polymer. Sol-gel process will make propagation inorganic chain of polymer, although photo-polymerization will make propagation organic chain of polymer. After photo-polymerization, organic and inorganic parts are crosslinked. Reflectance spectrum of hybrid polymer thin film before photopolymerization, after photo-polymerization and after post-bake show different of wave phase indicating different thickness of the thin films. Waveguide pattern is smooth and unbroken, indicates that polymerization of organic chain running well and stand after etching process.

Keywords : hybrid polymer; sol-gel process; photo-polymerization; waveguide pattern; etching process 


\section{. Pendahuluan}

Polimer merupakan bahan yang banyak digunakan dalam kehidupan sehari-hari. Polimer tersusun dari monomer-monomer yang berikatan secara kovalen membentuk suatu rantai panjang. Dalam bidang optik, polimer telah diaplikasikan untuk membuat serat optik, seperti polymethyl methacrylate (PMMA) yang termasuk dalam kategori polimer organik. Beberapa kendala pemanfaatan polimer organik yaitu stabilitas termal (Tg tidak mencapai $100^{\circ} \mathrm{C}$ ), resistansi kimiawi dan ketahanan terhadap cuaca yang lebih rendah dibandingkan bahan gelas. Di lain pihak, bahan gelas memiliki stabilitas termal yang baik (Tg mencapai $800^{\circ} \mathrm{C}$ ) dan transparan di daerah cahaya tampak. Namun, proses fabrikasinya harus dilakukan pada suhu tinggi. Hal ini tidak cocok dengan teknologi fabrikasi divais struktur nano dan mikro. Selain itu, suhu yang tinggi akan merusak molekul-molekul fungsional dan struktur yang telah dibangun sebelumnya [1].
Keterbatasan masing-masing bahan organik dan anorganik mendorong dikembangkannya polimer hibrid yang merupakan perpaduan antara polimer organik dan anorganik. Sifat optik polimer hibrid dapat dimodifikasi melalui variasi struktur dan jenis monomernya, serta penambahan material dopan atau molekul fungsionalnya. Sehingga peluang aplikasi optik menjadi sangat luas, seperti untuk coating solar cell, serat optik, dan host bahan luminesen untuk aplikasi optoelektronika seperti electronic displays, laser, dan penguat optic [2].

Dalam sepuluh tahun terakhir, polimer hibrid berbasis sol-gel digunakan sebagai bahan yang bisa dibuat pola (patternable) dengan cahaya untuk menghasilkan elemen optik mikro. Polimer hibrid yang mengandung unsur organik dan anorganik dalam satu molekul, diharapkan memiliki kombinasi sifat unggul dari bahan organik yang mudah dalam proses sintesis dan bahan anorganik yang memiliki sifat mekanik dan termal yang tinggi [3]. 
Untuk aplikasi dalam bidang mikrooptik, polimer hibrid digunakan sebagai bahan yang dapat dipola dengan teknik litografi. Dalam penelitian yang telah dilakukan, litografi solvent-assisted telah dilakukan dengan waktu pencahayaan yang singkat, dan intensitas sinar UV yang tidak terlalu tinggi digunakan untuk mempolimerisasi daerah yang terkena cahaya. Proses ini diikuti dengan proses menghilangkan area yang tidak disinari. Blanc dkk membuat proses litografi yang bebas pelarut (solvent-free) dan mengurangi tahap proses etching. Selain itu juga dikembangkan modifikasi dari proses yang memungkinkan untuk menghasilkan swelling dari bahan yang disinari dengan waktu yang singkat [4]. Ji-in Jung dkk membuat saluran pandu gelombang dengan menambahkan photolocking fotoinisiator dalam film polimer hibrid, dimana fotoinisiator dalam polimer hibrid terkunci dalam matriks dan menambah indeks bias dan ketebalan selama pencahayaan UV[5].

\section{Bahan dan Metode}

\subsection{Pembuatan Prekursor}

\section{Polimer Hibrid}

Pembuatan prekursor polimer hibrid dengan mentoda sol-gel menggunakan monomer 3-(Trimethoxysilyl) propyl methacrylate 98\% (TMSPMA, Aldrich), etanol $\left(\mathrm{C}_{2} \mathrm{H}_{5} \mathrm{OH}\right.$, Merck) sebagai pelarut, asam klorida $(\mathrm{HCl}$, Merck) sebagai katalis dan akuades $\left(\mathrm{H}_{2} \mathrm{O}\right)$. Hasil yang diperoleh dari proses sol-gel selanjutnya dipurifikasi untuk menghilangkan sisa monomer, air dan katalis yang tidak bereaksi. Sampel dibuat pada kondisi suhu $50^{\circ} \mathrm{C}$ dan kecepatan pengadukan sekitar $200 \mathrm{rpm}$.

\subsection{Pembuatan Film Tipis}

\section{Polimer Hibrid}

Dalam pembuatan film tipis, prekursor polimer hibrid dilarutkan dengan kloroform, kemudian ditambahkan fotoinisiator Irgacure819 (Ciba Speciality Chemical Inc.). Konsentrasi berat Irgacure 819 di dalam prekursor polimer hibrid divariasikan $0,3 \%$ wt dan $2 \%$ wt. Deposisi film dilakukan dengan 
teknik spin-coating dengan

kecepatan 3000 rpm selama 2 menit.

Setelah film tipis dihasilkan,

2.3. Pembuatan Pola Pandu dilakukan proses fotopolimerisasi

Gelombang Polimer Hibrid

yang dilakukan di dalam chamber

Pembuatan pola pandu gelombang

yang dialiri dengan gas nitrogen.

dilakukan dengan beberapa kondisi,

Sumber cahaya yang digunakan yang dituliskan dalam Tabel 1 . adalah laser dioda $(\lambda=405 \mathrm{~nm})$ dan lampu xenon. Proses Pembentukkan pola pandu gelombang polimer hibrid dilakukan fotopolimerisasi dilakukan selama 3 dengan meletakkan film tipis di menit. bawah mask yang sebelumnya dilapisi dengan spacer.

Tabel 1. Variasi sampel dan waktu penyinaran saat pembuatan pola pandu gelombang

\begin{tabular}{ccc}
\hline Sampel & Waktu Penyinaran (menit) & Keterangan \\
\hline PH-npb & $1,2,3$, dan 4 & Film tipis polimer hibrid tanpa pre-bake \\
\hline PH-npb & 1,5 dan 10 & Film tipis polimer hibrid tanpa pre-bake \\
\hline PH-pb & $1,2,3$, dan 4 & Film tipis polimer hibrid dengan pre-bake \\
\hline
\end{tabular}

\subsection{Karakterisasi}

Film tipis yang telah dibuat dikarakterisasi dengan spektrometer NanoCalc 2000 untuk mengukur spektrum reflektansinya.. Untuk mengetahui profil morfologi dari pola pandu gelombang polimer hibrid, digunakan mikroskop (National) yang sebelumnya telah dikalibrasi dengan pembesaran lensa okuler 10x dan pembesaran lensa objektif 10x. Mikroskop tersebut dihubungkan dengan komputer untuk melihat hasil pengamatannya dengan program Motic Plus 2.0 ML. Simulasi dengan program Matcad menggunakan persamaaan pemantulan jamak gelombang elektromagnetik dalam lapisan tipis dengan sinar datar sejajar dengan normal $(\theta=0)$. $R=r r^{*}=\frac{r_{1}^{2}+r_{2}^{2}+2 r_{1} r_{2} \cos (2 \delta)}{1+r_{1}^{2} r_{2}^{2}+2 r_{1} r_{2} \cos (2 \delta)}$ 
dimana

$r_{1}=\frac{n_{1}-n_{2}}{n_{1}+n_{2}}, \quad r_{2}=\frac{n_{2}-n_{3}}{n_{2}+n_{3}}$ dan

$\delta=\frac{2 \pi}{\lambda} n_{2} d$

dimana $\mathrm{n}_{1}=1$ (udara), $\mathrm{n}_{2}$ yaitu indeks bias lapisan tipis (polimer hibrid) dan $\mathrm{n}_{3}=3.7814$ (substrat silikon).

\section{Hasil dan Pembahasan}

\subsection{Pengukuran Indeks Bias dan}

\section{Ketebalan Film Tipis}

Hasil prekursor polimer hibrid yang terbentuk berupa gel yang kental dan bening. Spektrum reflektansi film tipis yang tidak di polimerisasi dan yang dipolimerisasi ditunjukkan pada Gambar 1. Spektum ini dicocokkan dengan simulasi Matchad 14 untuk menentukan besarnya indeks bias dan ketebalan film. Pada gambar 2 terlihat bahwa spektrum reflektansi film tanpa polimerisasi dan yang dipolimerisasi terjadi perbedaan periode gelombang, hal ini memungkinkan ada perbedaan ketebalan dan indeks biasnya.

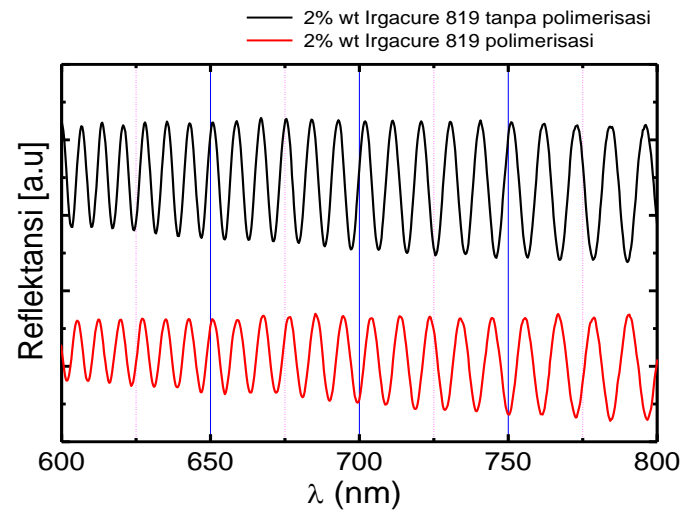

Gambar 1. Spektrum reflektansi film tipis tanpa polimerisasi dan yang dipolimerisasi

1. $0.3 \%$ wt Irgacure 819 


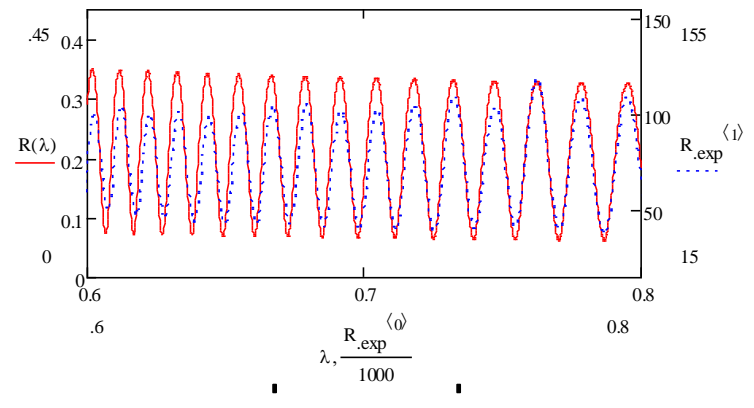

(a) Sebelum fotopolimerisasi, $\mathrm{d}=12.3 \mu \mathrm{m}$, $\mathrm{n}_{2}=1.50$

2. $2.0 \%$ wt Irgacure 819

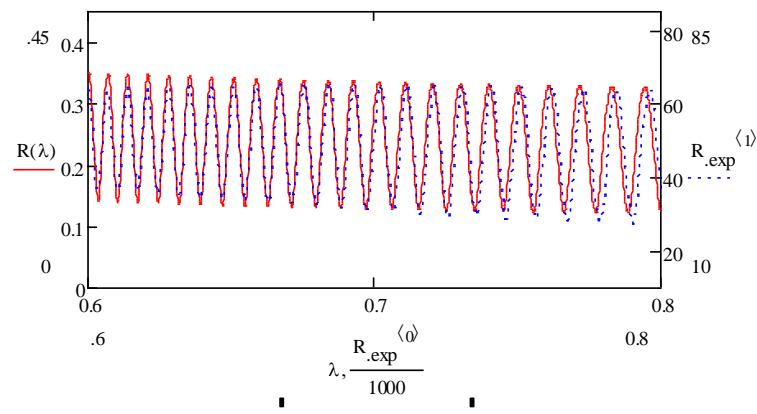

(c) Sebelum fotopolimerisasi, $\mathrm{d}=20.3 \mu \mathrm{m}$, $\mathrm{n}_{2}=1.50$

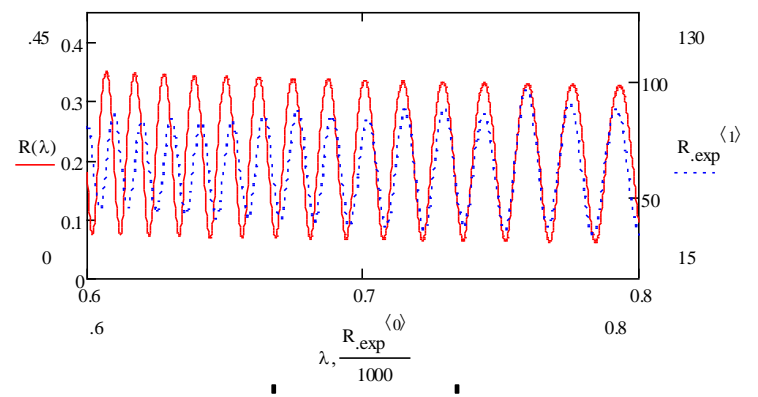

(b) Setelah fotopolimerisasi, $\mathrm{d}=12 \mu \mathrm{m}$,

$$
\mathrm{n}_{2}=1.50
$$

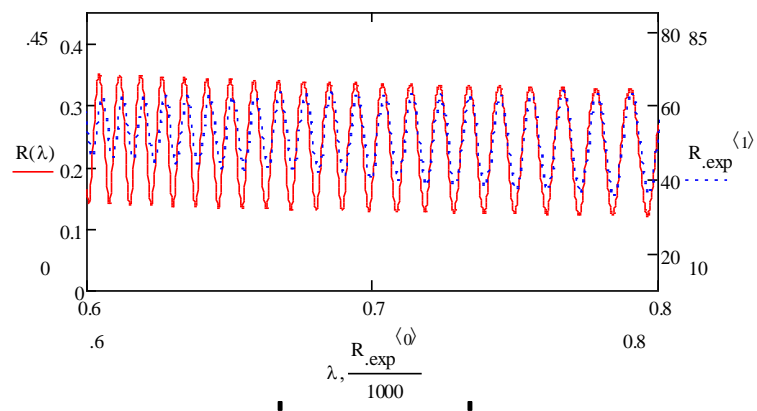

(d) Setelah fotopolimerisasi, $\mathrm{d}=19.3 \mu \mathrm{m}$, $\mathrm{n}_{2}=1.50$

Gambar 2. Spektrum reflektansi film tipis tanpa polimerisasi dan yang dipolimerisasi

Tabel 2 memperlihatkan

basah

saat

belum

perbandingan ketebalan film

difotopolimerisasi

kemudian

setelah dan sebelum

menjadi kering setelah

fotopolimerisasi untuk tiap

sampel, terlihat bahwa sampel 0,3

$\%$ wt mengalami penyusuutan

(shrinkage) sebesar $2,44 \%$,

fotopolimerisasi menunjukkan

terjadinya penyusutan volume

film tipis dan proses

fotopolimerisasi rantai organik

sedangkan pada sampel $2 \% \mathrm{wt}$

telah terjadi.

mengalami penyusutan sebesar

$4,93 \%$. Film tipis yang awalnya 
Tabel 2. Perbandingan ketebalan film sebelum dan sesudah fotopolimerisasi dengan variasi berat Irgacure 819

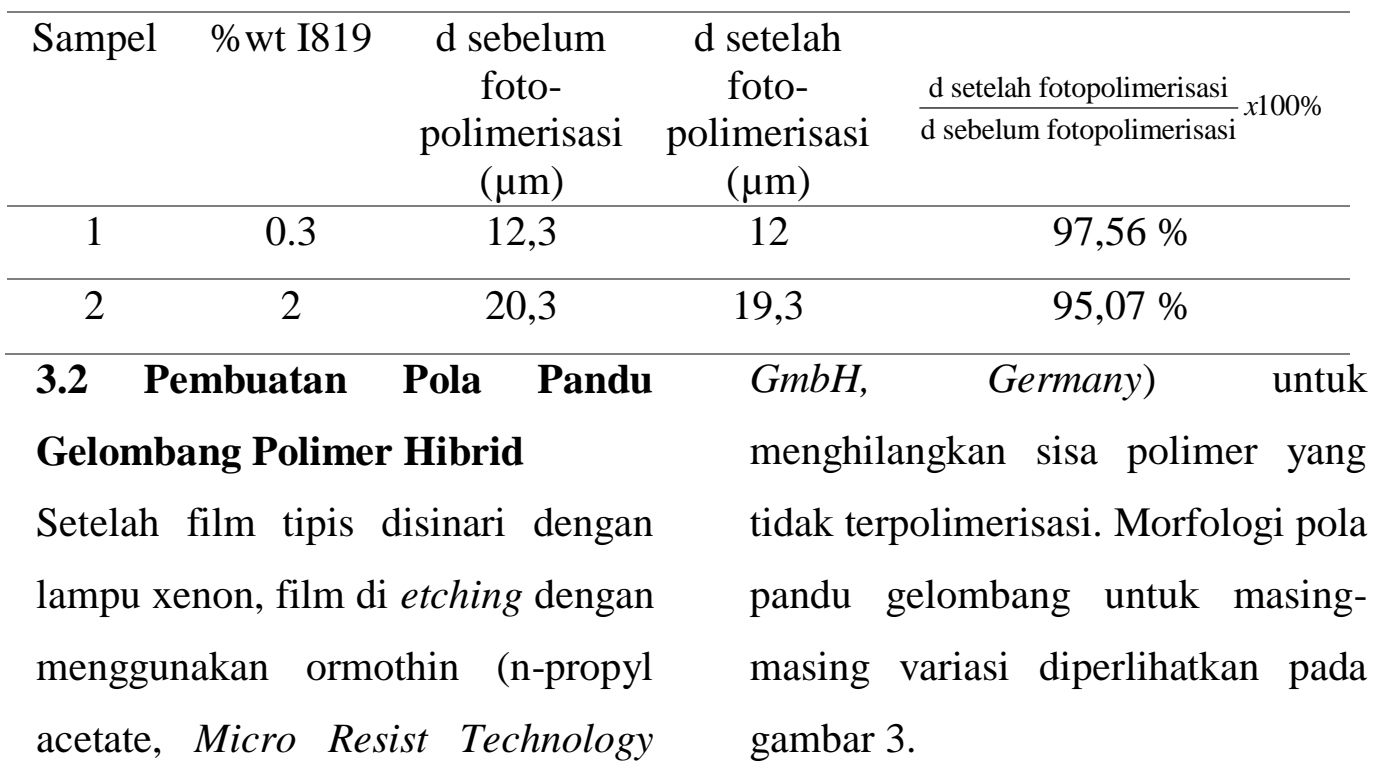

(a)

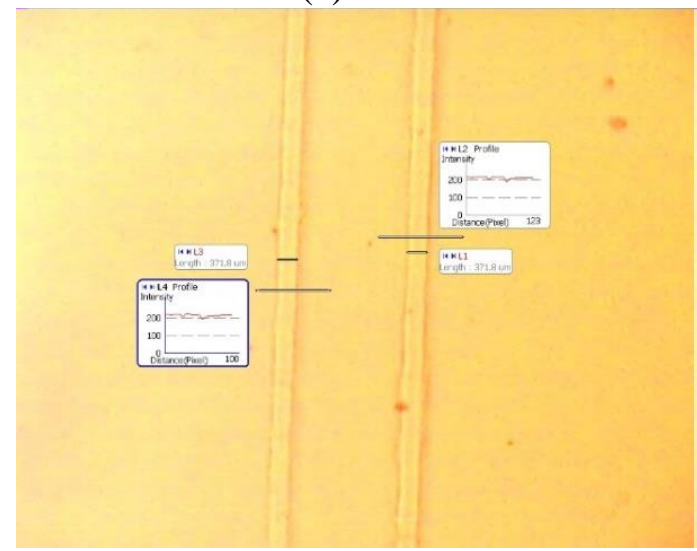

(c) (b)

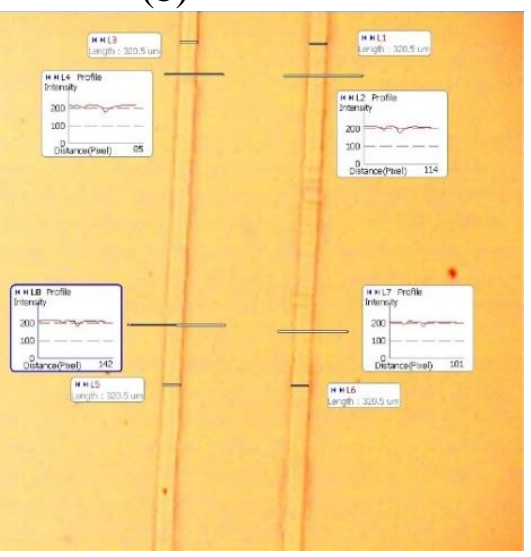

(d)

Gambar 3. Morfologi pola pandu gelombang tanpa pre-bake dengan waktu penyinaran (a) 1 menit, (b) 2 menit, (c) 3 menit, dan (d) 4 menit 
Saat diberikan waktu penyinaran 1 menit belum terbentuk pola, yang berarti belum ada proses polimerisasi rantai organik yang terjadi. Sedangkan saat waktu penyinaran 2 menit terbentuk pola namun terputus-putus, hal ini berkaitan dengan waktu yang kurang mencukupi sehingga inisiator belum sempurna mempropagasi rantai polimer organik. Waktu penyinaran selama 3 dan 4 menit menujukkan pola pandu gelombang yang jelas dan tidak terputus-putus, hal ini berkaitan dengan proses polimerisasi rantai organik yang telah terjadi dengan sempurna sehingga pola tidak terhapus saat di etching. Adapun morfologi pola pandu gelombang saat diberikan pre-bake dan variasi waktu penyinaran diperlihatkan pada gambar 5 . (a)

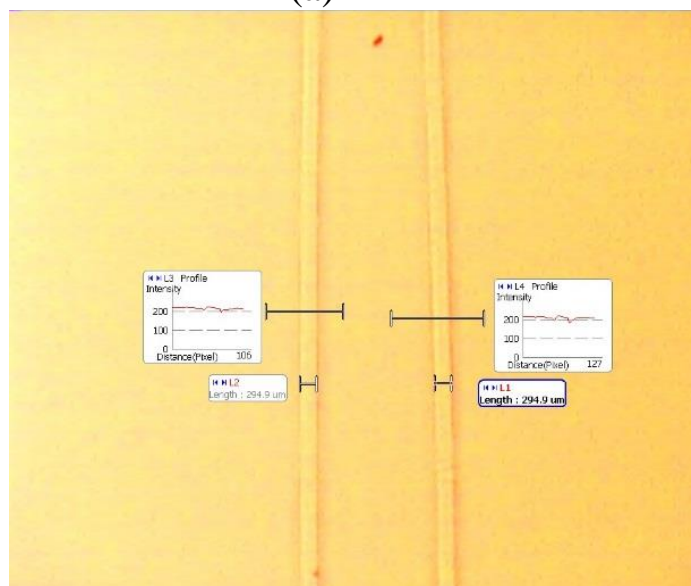

(c) (b)

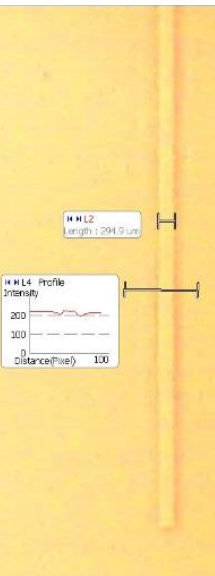

(d)

Gambar 4. Morfologi pola pandu gelombang dengan pre-bake dengan waktu penyinaran (a) 1 menit, (b) 2 menit, (c) 3 menit, dan (d) 4 menit 
Film tipis yang sudah berisi prekursor saja, sehingga saat didapatkan dengan teknik spin coating dilakukan fotopolimerisasi, pengikatan tidak langsung disinari dengan cahaya, rantai organik akan terbentuk lebih namun diberikan pemanasan terlebih baik.

dahulu untuk menghilangkan pelarut yang masih ada di dalam film. Setelah di fotopolimerisasi dan di etching, terlihat bahwa untuk waktu penyinaran 1 menit belum menghasilkan pola. Sedangkan untuk waktu penyinaran 2 menit sudah menghasilkan pola, namun terlihat belum mulus dan ada bagianbagian yang bergelombang. Adapun

Pemanasan setelah film tipis di fotopolimerisasi (post-bake) berfungsi untuk meningkatkan daya rekat film terhadap substrat. Prekursor yang sudah dideposisi menjadi film tipis, kemudian di pre-bake dan di fotopolimerisasi selama 4 menit, diberikan post-bake dengan variasi untuk waktu penyinaran 3 dan 4 menit, waktu 1 menit, 5 menit dan 10 menit. pola yang dihasilkan sudah mulus dan tidak terputus-putus. Pola pandu gelombang dengan pre-bake menghasilkan pola yang lebih jelas dibandingkan dengan yang tanpa prebake, terlihat saat penyinaran 2 menit, pola dengan pre-bake dapat lebih jelas terbentuk dibandingkan yang tanpa pre-bake yang terputus-putus. Untuk yang 3 dan 4 menit, polanya lebih jelas jika diberikan pre-bake. Pre-bake yang berfungsi untuk menghilangkan Morfologi film tipis dengan variasi waktu post-bake diperlihatkan pada gambar 5. Pola pandu gelombang polimer hibrid dengan variasi waktu post-bake menunjukkan pola yang jelas dan tidak terputus-putus. Selain itu, waktu post-bake selama 1, 5 dan 10 menit tidak membuat sisa polimer yang tidak terkenai cahaya mengalami polimerisasi, yang akan membuat sisa polimer tidak bisa dibuang saat proses pelarut, akan membuat film hanya etching. 


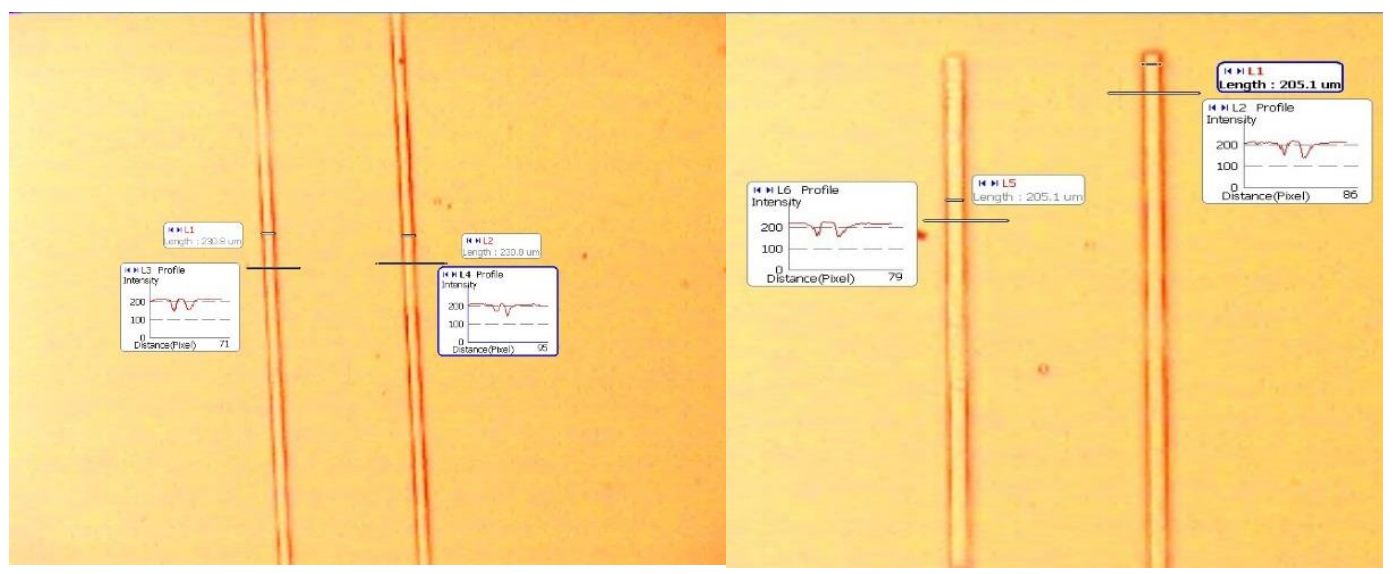

(a)

(b)

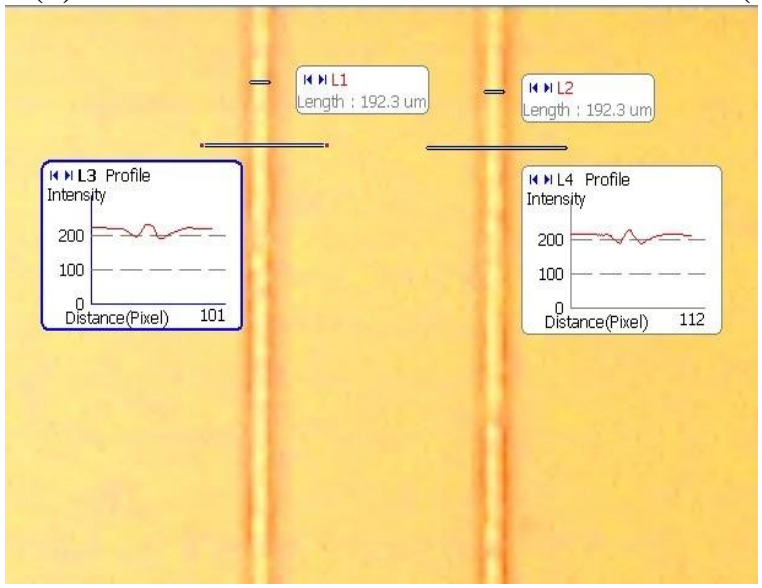

(c)

Gambar 5. Morfologi pola pandu gelombang dengan pre-bake dengan waktu penyinaran 4 menit dan variasi waktu post-bake (a) 1 menit, (b) 5 menit, dan (c) 10 menit

4.

\section{Simpulan}

Dalam penelitian ini telah berhasil dilakukan preparsi prekursor polimer hibrid TMSPMA dengan metode sol-gel, dan preparasi film tipis polimer hibrid dengan proses foto-polimerisasi. Fotopolimerisasi dengan menggunakan sumber cahaya laser biru $(\lambda=405 \mathrm{~nm})$ dapat menginisiasi fotoinisiator Irgacure
819, dan menjadikan film menjadi keras. hal ini menunjukkan bahwa rantai organik dalam polimer telah berikatan silang (cross-link). Simulasi pengukuran ketebalan dan indeks bias film tipis dengan variasi konsentrasi berat Irgacure 819 menghasilkan film dengan ketebalan yang berbeda namun indeks bias nya relatif tetap yaitu 1,50. Sampel 
dengan variasi konsentrasi berat Irgacure 819 mengalami penyusutan volume film sebesar $2,44 \%$ dan $4,93 \%$.

Pola pandu gelombang dengan menggunakan polimer hibrid TMSPMA berhasil dilakukan dan menghasilkan pandu gelombang dengan bentuk struktur kanal persegi yang baik dan tidak terputus-putus. Pola pandu gelombang yang diberikan pre-bake relatif lebih baik dibandingkan yang tanpa diberikan pre-bake, dilihat dari strukturnya yang lebih solid dan tidak terputusputus. Sedangkan yang diberikan post-bake tidak memberikan hasil yang lebih baik dari sampel sebelumnya. Hasil eksperimen ini menunjukkan bahwa proses sol-gel yang dilakukan menghasilkan polimer hibrid yang memiliki kemungkinan yang baik untuk aplikasi komponen optik.

\section{Ucapan Terima Kasih}

Penulis mengucapkan terimakasih kepada Laratorium Elektronika Fisika ITB yang memberikan fasilitas pengukuran mikroskop.

\section{Referensi}

1. Cowie, J.M.G. (1991). Polymers : Chemistry \& Physics of Modern Materials. United Kingdom : Chapman \& Hall.

2. Kickelbick, Guido. (2007). Hybrid Materials.Wiley-VCH Verlag GmbH \& Co. KgaA.

3. Haas, Karl-Heinz. (2003). Hybrid Inorganic/Organic Polymers with Nanoscale Building Blocks : Precursors, Processing, Properties and Applications. ISC Fraunhofer Institut für Silikatforschung, Würzburg, Germany.

4. Blanc, D et al. (2003). PhotoInduced Swelling of Hybrid SolGel Thin Films : Application to Surface Micro-Patterning. Journal of Sol-Gel Science and Technology 27. 215-220.

5. Jung, Ji-in et al (2003). Fabrication of Channel Waveguides by Photochemical Self-Developing in Doped SolGel Hybrid Glass. Journal of Sol-Gel Science and Technology 26:897-901. 